\title{
Piscibacillus salipiscarius gen. nov., sp. nov., a moderately halophilic bacterium from fermented fish (pla-ra) in Thailand
}

Correspondence

Somboon Tanasupawat

Somboon.T@chula.ac.th

\author{
Somboon Tanasupawat, ${ }^{1}$ Sirilak Namwong, ${ }^{2}$ Takuji Kudo $^{3}$ \\ and Takashi Itoh ${ }^{3}$
}

\author{
${ }^{1}$ Department of Microbiology, Faculty of Pharmaceutical Sciences, Chulalongkorn University, \\ Bangkok 10330, Thailand \\ ${ }^{2}$ Faculty of Science \& Technology, Suan Sunandha Rajabhat University, Bangkok 10300, \\ Thailand \\ ${ }^{3}$ Japan Collection of Microorganisms, RIKEN BioResource Center, Wako-shi, \\ Saitama 351-0198, Japan
}

\begin{abstract}
A Gram-positive, spore-forming and moderately halophilic bacterium was isolated from fermented fish (pla-ra) in Thailand. Cells of the isolate, RBU $1-1^{\top}$, were strictly aerobic, motile rods and contained meso-diaminopimelic acid in the cell-wall peptidoglycan. Menaquinone with seven isoprene units (MK-7) was the predominant quinone. This isolate grew at $15-48{ }^{\circ} \mathrm{C}, \mathrm{pH} 5-9$ and in $2-30 \% \mathrm{NaCl}$ (optimally 10-20\%). The major cellular fatty acids were iso- $\mathrm{C}_{15: 0}$ and anteiso- $\mathrm{C}_{15: 0}$. Polar lipid analysis revealed the presence of phosphatidylglycerol and diphosphatidylglycerol. The DNA G +C content was 36.7 mol\%. 16S rRNA gene sequence analysis revealed that strain RBU $1-1^{\top}$ was a member of the family Bacillaceae, and belonged to a cluster with Filobacillus and Tenuibacillus; strain RBU1-1 ${ }^{\top}$ showed $16 \mathrm{~S}$ rRNA gene sequence similarities of $96.0-96.9 \%$ to members of these two genera. Strain RBU1-1 ${ }^{\top}$ could also be differentiated from members of the genera Filobacillus and Tenuibacillus based on certain phenotypic characteristics such as cell-wall composition, mode of flagellation and growth $\mathrm{pH}$ range. Therefore, strain RBU $1-1^{\top}$ is considered to represent a novel species in a new genus in the family Bacillaceae, for which the name Piscibacillus salipiscarius gen. nov., sp. nov. is proposed. The type strain of Piscibacillus salipiscarius is RBU $1-1^{\top}\left(=\mathrm{JCM} 13188^{\top}=\mathrm{PCU} 270^{\top}=\right.$ TISTR $\left.1571^{\top}\right)$.
\end{abstract}

Moderately halophilic, aerobic, endospore-forming, Grampositive, rod-shaped bacteria, isolated from various saline environments, such as marine environments, salt lakes and fermented fish-foods, are widely found in the family Bacillaceae, with representatives in the genera Bacillus, Halobacillus, Virgibacillus, Filobacillus, Oceanobacillus, Lentibacillus, Paraliobacillus, Pontibacillus, Tenuibacillus, Salinibacillus, Alkalibacillus and Thalassobacillus (Ventosa et al., 1989; Spring et al., 1996; Heyndrickx et al., 1999; Schlesner et al., 2001; Lu et al., 2001; Yoon et al., 2002; Ishikawa et al., 2002; Lim et al., 2005; Ren \& Zhou, 2005a, b; Jeon et al., 2005; García et al., 2005). Recently, we have described novel species of the genus Lentibacillus, Lentibacillus juripiscarius and Lentibacillus halophilus from fish

\footnotetext{
Abbreviation: meso-DAP, meso-diaminopimelic acid.

The GenBank/EMBL/DDBJ accession number for the 16S rRNA gene sequence of RBU1-1 ${ }^{\top}$ is $A B 194046$.

A chromatogram of the polar lipids of strain $\mathrm{RBU} 1-1^{\top}$ is available as a supplementary figure with the online version of this paper.
}

sauce (Namwong et al., 2005; Tanasupawat et al., 2006) and Lentibacillus kapialis from fermented shrimp paste (Pakdeeto et al., 2007), suggesting that such fermented foods may harbour many undescribed species of halophilic or halotolerant bacteria. Here we describe the isolation and phenotypic, chemotaxonomic and phylogenetic properties of a novel, moderately halophilic isolate, designated RBU1-1 ${ }^{\mathrm{T}}$, from pla-ra (fermented fish), which is fermented mainly from freshwater fish and contains roasted rice and high levels of added salt (Phithakpol et al., 1995).

Strain RBU $1-1^{\mathrm{T}}$ was isolated from fermented fish (pla-ra) collected from a market in Ratchaburi Province, Thailand. Isolation was by the spread-plate technique on agar plates of JCM medium no. 377 (designated Lentibacillus medium; Namwong et al., 2005) incubated at $37^{\circ} \mathrm{C}$ for 7 days. Strain RBU $1-1^{\mathrm{T}}$ and reference strain Filobacillus milosensis JCM $12288^{\mathrm{T}}$ were routinely cultivated in JCM medium no. 377.

Cell form, cell size, cell arrangement and colonial appearance were examined for cells grown on Lentibacillus medium 
at $37^{\circ} \mathrm{C}$ for 5 days. The Gram reaction was investigated according to the procedures of Hucker \& Conn (1923). Critical-point-dried cells and spores were observed under a scanning electron microscope. Flagella were stained by the method described by Forbes (1981). Tests for catalase, oxidase, indole production, Simmons' citrate, nitrate reduction and hydrolysis of DNA, starch, tyrosine, Tween 80, phenylalanine, xanthine and hypoxanthine were performed according to the methods of Barrow \& Feltham (1993). The test for arginine hydrolysis was performed by using the medium given by Thornley (1960). Casamino acids in JCM medium no. 377 were omitted from the test medium for determination of the hydrolysis of gelatin and casein. Urease was detected on Christensen's medium (Barrow \& Feltham, 1993) supplemented with $10 \% \mathrm{NaCl}$. Acid production from carbohydrate was determined in the medium described by Leifson (1963) supplemented with $6.5 \% \mathrm{NaCl}$. Growth under anaerobic conditions on agar plates was performed by using a Gaspak (BBL). Growth at various temperatures $\left(5-60^{\circ} \mathrm{C}\right)$ was examined by using a temperature gradient incubator (model $\mathrm{TN}-3$; Advantec). $\mathrm{NaCl}$ requirement for growth was determined in the medium containing various $\mathrm{NaCl}$ concentrations (0-30\%). At lower $\mathrm{NaCl}$ concentrations (0-2.0\%), $\mathrm{MgSO}_{4} \cdot 7 \mathrm{H}_{2} \mathrm{O}$ was omitted from the test medium and $\mathrm{KCl}$ and trisodium citrate were used. Growth was monitored by measuring culture turbidity at $660 \mathrm{~nm}$. Isomers of diaminopimelic acid (DAP) in the peptidoglycan and menaquinones were analysed as described by Komagata \& Suzuki (1987). Polar lipids were determined according to the method of Minnikin et al. (1984). Quantitative analysis of cellular fatty acids was done with the Microbial Identification System (MIDI) (Sasser, 1990; Kämpfer \& Kroppenstedt, 1996). DNA was isolated from cells grown in JCM no. 377 medium broth incubated on a rotary shaker ( 150 r.p.m.) at $37^{\circ} \mathrm{C}$ for 2 days and was purified according to the method of Saito \& Miura (1963). The DNA G+C content was determined by the method of Tamaoka \& Komagata (1984) by using reversedphase HPLC. DNA-DNA hybridization experiments were conducted as described by Ezaki et al. (1989) and with the colorimetric method as reported by Tanasupawat et al. (2000). 16S rRNA gene fragments were amplified by PCR and the sequence was determined as described by Tanasupawat et al. (2004). The $16 \mathrm{~S}$ rRNA gene sequence was multiply aligned with the program CLUSTAL_X (Thompson et al., 1997); the alignment was manually verified and edited prior to construction of a phylogenetic tree. The phylogenetic tree was constructed by using the neighbour-joining method (Saitou \& Nei, 1987) in the program MEGA, version 2.1 (Kumar et al., 2001). Confidence values of branches of the phylogenetic tree were determined by using bootstrap analyses (Felsenstein, 1985) based on 1000 resampled datasets.

Cells of strain RBU1-1 ${ }^{\mathrm{T}}$ were Gram-positive rods, $0.4-0.5 \times$ $1.5-4 \mu \mathrm{m}$ in size, and motile with peritrichous flagella. Oval to spherical endospores were formed at cell-terminal positions in swollen sporangia (Fig. 1). Colonies were white to cream, $0.9-3.9 \mathrm{~mm}$ in diameter after 5 days cultivation on Lentibacillus agar medium. Results of physiological,

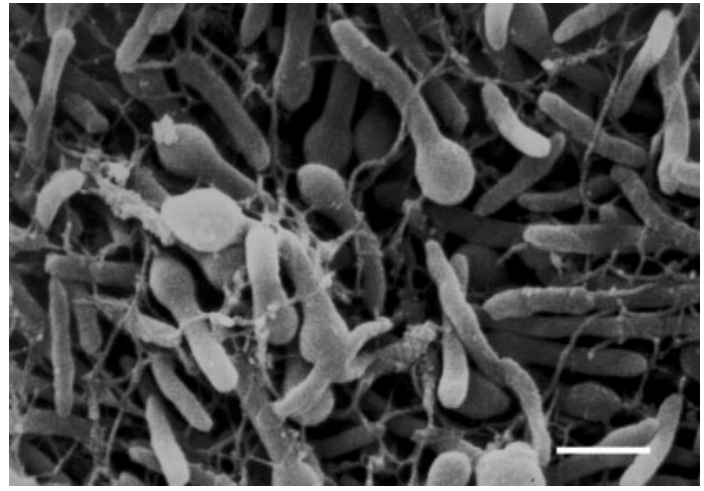

Fig. 1. Scanning electron micrograph of cells of strain RBU1-1 ${ }^{\top}$ grown on JCM no. 377 medium at $37^{\circ} \mathrm{C}$. Bar, $1 \mu \mathrm{m}$.

biochemical and chemotaxonomic tests are given in the species description below and in Table 1 .

16S rRNA gene sequence comparisons with known aerobic, Gram-positive, spore-forming halophilic bacteria revealed that strain RBU1-1 ${ }^{\mathrm{T}}$ formed a cluster together with $F$. milosensis SH714 ${ }^{\mathrm{T}}$ and Tenuibacillus multivorans NBRC $100370^{\mathrm{T}}$, with high bootstrap support $(88 \%)$, and this cluster was also closely related to another cluster of Alkalibacillus species with $92 \%$ bootstrap support, as shown in Fig. 2. 16S rRNA gene sequence similarity values between strain RBU $1-1^{\mathrm{T}}$ and F. milosensis $\mathrm{SH} 714^{\mathrm{T}}$ and T. multivorans NBRC $100370^{\mathrm{T}}$ were 96.9 and $96 \%$, respectively, while values between strain RBU1-1 ${ }^{\mathrm{T}}$ and species of the genus Alkalibacillus were in the range $94-95.3 \%$. In addition, strain RBU1-1 ${ }^{\mathrm{T}}$ was related to members of the genera Bacillus (sensu lato), Halobacillus, Virgibacillus, Oceanobacillus, Lentibacillus, Paraliobacillus, Pontibacillus, Salinibacillus and Thalassobacillus with levels of 16S rRNA gene sequence similarity of $91.5-94.7 \%$. In DNA-DNA hybridization experiments (Wayne et al., 1987), labelled DNA from $F$. milosensis JCM $12288^{\mathrm{T}}$ showed 9.5\% DNA-DNA relatedness to strain RBU1-1 ${ }^{\mathrm{T}}$, and reciprocally, that of RBU1-1 ${ }^{\mathrm{T}}$ showed $23.4 \%$ DNA-DNA relatedness to $F$. milosensis JCM $12288^{\mathrm{T}}$.

Strain RBU1- $1^{\mathrm{T}}$ is a moderately halophilic, aerobic, sporeforming, Gram-positive, rod-shaped bacterium belonging to the family Bacillaceae. 16S rRNA gene sequence analysis revealed that strain $\mathrm{RBU} 1-\mathrm{1}^{\mathrm{T}}$ is related closely to the monospecific genera Filobacillus and Tenuibacillus. In agreement with the phylogenetic relationships, strain RBU1- $1^{\mathrm{T}}$ shared similar DNA G $+C$ content range, polar lipid pattern and fatty acid profile with these two genera. However, $F$. milosensis JCM $12288^{\mathrm{T}}$ has L-ornithine as the diagnostic diamino acid in the cell wall, whereas strain RBU1-1 ${ }^{\mathrm{T}}$ and T. multivorans NBRC $100370^{\mathrm{T}}$ have meso-DAP. Strain RBU1- $1^{\mathrm{T}}$ and T. multivorans can be differentiated phenotypically, for example based on mode of flagellation and acid tolerance. On the other hand, strain RBU1- $1^{\mathrm{T}}$ is related quite closely phylogenetically to members of the genus Alkalibacillus; however, all Alkalibacillus species are 
Table 1. Differential characteristics between strain RBU $1-1^{\top}$ and related taxa

Taxa: 1, strain RBU1-1 ${ }^{\mathrm{T}}$; 2, Filobacillus (data from this study and Schlesner et al., 2001); 3, Tenuibacillus (Ren \& Zhou, 2005a); 4, Alkalibacillus (Fritze, 1996; Jeon et al., 2005). +, Positive; w, weakly positive; -, negative; NA, not available. All taxa produce spores in a terminal position.

\begin{tabular}{|c|c|c|c|c|}
\hline Characteristic & 1 & 2 & 3 & 4 \\
\hline Gram reaction & + & - & + & + \\
\hline $\mathrm{NaCl}$ range $(\%, \mathrm{w} / \mathrm{v})$ & $2-30$ & $2-23$ & $1-20$ & $0-25$ \\
\hline Maximum growth temperature $\left({ }^{\circ} \mathrm{C}\right)$ & 48 & 42 & 42 & 40 \\
\hline Growth at $\mathrm{pH} 6.0$ & + & - & - & - \\
\hline \multicolumn{5}{|l|}{ Hydrolysis of: } \\
\hline Gelatin & + & - & + & + \\
\hline Casein & + & - & + & + \\
\hline Starch & + & - & - & $\mathrm{w}$ \\
\hline Murein type & meso-DAP & L-Orn & meso-DAP & meso-DAP \\
\hline
\end{tabular}

alkalophilic (Fritze, 1996; Jeon et al., 2005; Romano et al., 2005). Differential characteristics between strain RBU1-1 ${ }^{\mathrm{T}}$ and the genera Filobacillus, Tenuibacillus and Alkalibacillus are given in Table 1.

Strain RBU1-1 ${ }^{\mathrm{T}}$ can be separated from the genera Filobacillus, Tenuibacillus and Alkalibacillus and is considered to represent a novel species of a new genus. We propose the name Piscibacillus salipiscarius gen. nov., sp. nov. to accommodate this organism.

\section{Description of Piscibacillus gen. nov.}

Piscibacillus (Pis.ci.ba.cil'lus. L. n. piscis fish; L. masc. n. bacillus small rod; N.L. masc. n. Piscibacillus a rod from fish).

Gram-positive rods, measuring $0.4-0.5 \times 1.5-4 \mu \mathrm{m}$. Cells are motile with peritrichous flagella. Oval terminal endospores are formed in swollen sporangia. Positive for catalase and oxidase, but negative for urease and reduction

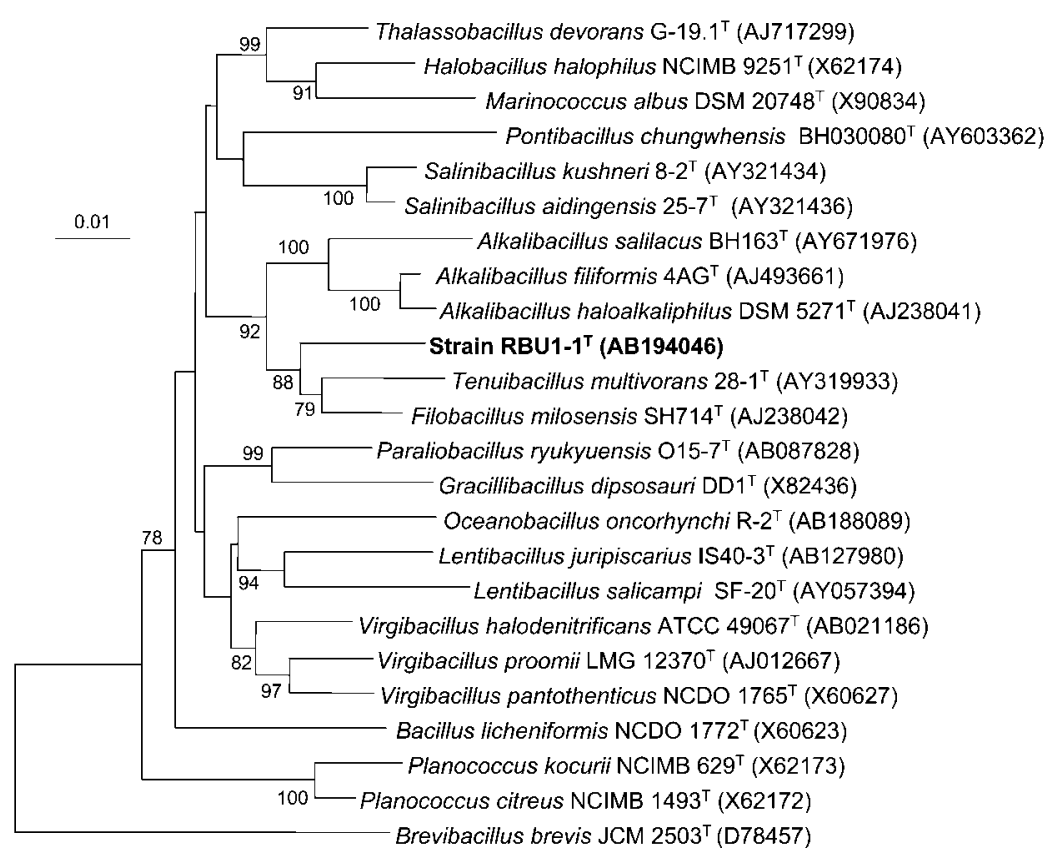

Fig. 2. Phylogenetic tree showing the relationships between strain RBU $1-1^{\top}$ and related bacterial species based on 16S rRNA gene sequences. The branching pattern was generated by the neighbour-joining method. Bootstrap percentages $\geqslant 78 \%$, based on 1000 replications, are shown at nodes. Bar, 1 substitution per 100 nucleotide positions. 
Table 2. Cellular fatty acid composition of strains RBU1-1 ${ }^{\top}$ and F. milosensis JCM $12288^{\top}$

Values are percentage of total fatty acids. ND, Not detected.

\begin{tabular}{|lcc|}
\hline Fatty acid & RBU1-1 $^{\mathbf{T}}$ & F. milosensis JCM $\mathbf{~ 1 2 2 8 8 ~}^{\mathbf{T}}$ \\
\hline Saturated & & \\
$\mathrm{C}_{14: 0}$ & 0.2 & 0.2 \\
$\mathrm{C}_{15: 0}$ & 0.5 & 0.6 \\
$\mathrm{C}_{16: 0}$ & 1.3 & 1.3 \\
$\mathrm{C}_{16: 0} \mathrm{~N}$ alcohol & 0.8 & 0.2 \\
Unsaturated & & \\
$\mathrm{C}_{16: 1} \omega 7 c$ & 2.0 & 1.1 \\
$\mathrm{C}_{16: 1} \omega 11 c$ & 1.2 & 0.2 \\
Branched-chain & & \\
iso- $\mathrm{C}_{14: 0}$ & 4.5 & 2.7 \\
iso- $\mathrm{C}_{15: 0}$ & 35.3 & 23.2 \\
anteiso- $\mathrm{C}_{15: 0}$ & 30.8 & 41.5 \\
iso- $\mathrm{C}_{16: 0}$ & 10.1 & 9.5 \\
iso- $\mathrm{C}_{17: 0}$ & 3.5 & 4.0 \\
anteiso- $\mathrm{C}_{17: 0}$ & 6.1 & 11.2 \\
iso- $\mathrm{C}_{19: 0}$ & $\mathrm{ND}$ & 0.4 \\
anteiso- $\mathrm{C}_{19: 0}$ & $\mathrm{ND}$ & 0.2 \\
\hline
\end{tabular}

of nitrate, production of indole and utilization of citrate. Casein, DNA and gelatin are hydrolysed, but arginine, starch, Tween 80, tyrosine, phenylalanine, xanthine and hypoxanthine are not. meso-DAP is present in the peptidoglycan. The predominant menaquinone is MK-7. The major fatty acids are iso- $\mathrm{C}_{15: 0}$ and anteiso- $\mathrm{C}_{15: 0}$ (Table 2). Phosphatidylglycerol and diphosphatidylglycerol are the predominant polar lipids (see Supplementary Fig. S1 in IJSEM Online). The type species is Piscibacillus salipiscarius.

\section{Description of Piscibacillus salipiscarius sp. nov.}

Piscibacillus salipiscarius (sa.li.pis.ca' ri.us. L. n. sal, salis salt; L. adj. piscarius of or belonging to fish; N.L. masc. adj. salipiscarius of or belonging to a salted fish).

Colonies are white to cream, 0.9-3.9 $\mathrm{mm}$ in diameter after 5 days growth on Lentibacillus agar medium. Grows aerobically but weakly under anaerobic conditions. Grows at 15-48 ${ }^{\circ} \mathrm{C}$ (optimally at $37^{\circ} \mathrm{C}$ ), $\mathrm{pH}$ 5-9 (optimally at pH 7.0) and in $2-30 \% \mathrm{NaCl}$ (optimally in 10-20\%). Acid is produced from D-fructose, D-galactose, D-glucose, glycerol, Dribose and sucrose, but not from D-amygdalin, L-arabinose, cellobiose, inulin, lactose, maltose, mannitol, D-mannose, melibiose, melezitose, methyl $\alpha$-D-glucoside, myo-inositol, raffinose, rhamnose, salicin, sorbitol, trehalose or D-xylose. The DNA G + C content of the type strain is $36.7 \mathrm{~mol} \%$.

The type strain, RBU1- $1^{\mathrm{T}}\left(=\mathrm{JCM} 13188^{\mathrm{T}}=\right.$ PCU $270^{\mathrm{T}}=$ TISTR $1571^{\mathrm{T}}$ ), was isolated from fermented fish (pla-ra) in Thailand.

\section{Acknowledgements}

This study was supported in part by a Rachadapiseksomphot Research Grant, Chulalongkorn University (2002).

\section{References}

Barrow, G. I. \& Feltham, R. K. A. (1993). Cowan and Steel's Manual for the Identification of Medical Bacteria, 3rd edn. Cambridge: Cambridge University Press.

Ezaki, T., Hashimoto, Y. \& Yabuuchi, E. (1989). Fluorometric deoxyribonucleic acid-deoxyribonucleic acid hybridization in microdilution wells as an alternative to membrane filter hybridization in which radioisotopes are used to determine genetic relatedness among bacterial strains. Int J Syst Bacteriol 39, 224-229.

Felsenstein, J. (1985). Confidence limits on phylogenies: an approach using the bootstrap. Evolution 39, 783-791.

Forbes, L. (1981). Rapid flagella stain. J Clin Microbiol 13, 807-809. Fritze, D. (1996). Bacillus haloalkalophilus sp. nov. Int J Syst Bacteriol 46, 98-101.

Garcia, M. T., Gallego, V., Ventosa, V. \& Mellado, E. (2005). Thalassobacillus devorans gen. nov., sp. nov., a moderately halophilic, phenol-degrading, Gram-positive bacterium. Int J Syst Evol Microbiol 55, 1789-1795.

Heyndrickx, M., Lebbe, L., Kersters, K., Hoste, B., De Wachter, R., De Vos, P., Forsyth, G. \& Logan, N. A. (1999). Proposal of Virgibacillus proomii sp. nov. and emended description of Virgibacillus panthothenticus (Proom and Knight 1950) Heyndrickx et al. 1998. Int J Syst Bacteriol 49, 1083-1090.

Hucker, G. J. \& Conn, H. J. (1923). Method of gram staining. Tech Bull N Y St Agric Exp Sta 93, 3-37.

Ishikawa, M., Ishizaki, S., Yamamoto, Y. \& Yamasato, K. (2002). Paraliobacillus ryukyuensis gen. nov., sp. nov., a new Gram-positive, slightly halophilic, extremely halotolerant, facultative anaerobe isolated from a decomposing marine alga. J Gen Appl Microbiol 48, 269-279.

Jeon, C. O., Lim, J.-M., Lee, J.-M., Xu, L.-H., Jiang, C.-L. \& Kim, C.-J. (2005). Reclassification of Bacillus haloalkaliphilus Fritze 1996 as Alkalibacillus haloalkaliphilus gen. nov., comb. nov. and the description of Alkalibacillus salilacus sp. nov., a novel halophilic bacterium isolated from a salt lake in China. Int J Syst Evol Microbiol 55, 1891-1896.

Kämpfer, P. \& Kroppenstedt, R. M. (1996). Numerical analysis of fatty acid patterns of coryneform bacteria and related taxa. Can J Microbiol 42, 989-1005.

Komagata, K. \& Suzuki, K. (1987). Lipid and cell-wall analysis in bacterial systematics. Methods Microbiol 19, 161-207.

Kumar, S., Tamura, K., Jakobson, I.-B. \& Nei, M. (2001). MEGA2: molecular evolutionary genetic analysis software. Bioinformatics 17, 1244-1245.

Leifson, E. (1963). Determination of carbohydrate metabolism of marine bacteria. J Bacteriol 85, 1183-1184.

Lim, J.-M., Jeon, C. O., Sung, S. M. \& Kim, C.-J. (2005). Pontibacillus chungwhensis gen. nov., sp. nov., a moderately halophilic Grampositive bacterium from a solar saltern in Korea. Int J Syst Evol Microbiol 55, 165-170.

Lu, J., Nogi, Y. \& Takami, H. (2001). Oceanobacillus iheyensis gen. nov., sp. nov., a deep-sea extremely halotolerant and alkaliphilic species isolated from a depth of $1050 \mathrm{~m}$ on the Iheya Ridge. FEMS Microbiol Lett 205, 291-297.

Minnikin, D. E., O’Donnell, A. G., Goodfellow, M., Alderson, G., Athalye, M., Schaal, A. \& Parlett, J. H. (1984). An integrated procedure for the extraction of bacterial isoprenoid quinones and polar lipids. J Microbiol Methods 2, 233-241. 
Namwong, S., Tanasupawat, S., Smitinont, T., Visessanguan, W., Kudo, T. \& Itoh, T. (2005). Isolation of Lentibacillus salicampi strains and Lentibacillus juripiscarius sp. nov. from fish sauce in Thailand. Int J Syst Evol Microbiol 55, 315-320.

Pakdeeto, A., Tanasupawat, S., Thawai, C., Moonmangmee, S., Kudo, T. \& Itoh, T. (2007). Lentibacillus kapialis sp. nov., from fermented shrimp paste in Thailand. Int J Syst Evol Microbiol 57, 364-369.

Phithakpol, B., Varanyanond, W., Reungmaneepaitoon, S. \& Wood, H. (1995). The Traditional Fermented Foods of Thailand. Kuala Lumpur: ASEAN Food Handling Bureau Level 3.

Ren, P.-G. \& Zhou, P.-J. (2005a). Tenuibacillus multivorans gen. nov., sp. nov., a moderately halophilic bacterium isolated from saline soil in Xin-Jiang, China. Int J Syst Evol Microbiol 55, 95-99.

Ren, P.-G. \& Zhou, P.-J. (2005b). Salinibacillus aidingensis gen. nov., sp. nov., and Salinibacillus kushneri sp. nov., moderately halophilic bacteria isolated from a neutral saline lake in Xin-Jiang, China. Int J Syst Evol Microbiol 55, 949-953.

Romano, I., Lama, L., Nicolaus, B., Gambacorta, A. \& Giordano, A. (2005). Alkalibacillus filiformis sp. nov., isolated from a mineral pool in Campania, Italy. Int J Syst Evol Microbiol 55, 2395-2399.

Saito, H. \& Miura, K. (1963). Preparation of transforming deoxyribonucleic acid by phenol treatment. Biochim Biophys Acta 72, 619-629.

Saitou, N. \& Nei, M. (1987). The neighbor-joining method: a new method for reconstructing phylogenetic trees. Mol Biol Evol 4, 406-425.

Sasser, M. (1990). Identification of bacteria by gas chromatography of cellular fatty acids. MIDI Technical Note 101. Newark, DE: MIDI Inc.

Schlesner, H., Lawson, P. A., Collins, M. D., Weiss, N., Wehmeyer, U., Völker, H. \& Thomm, M. (2001). Filobacillus milensis gen. nov., sp. nov., a new halophilic spore-forming bacterium with Orn-D-Glutype peptidoglycan. Int J Syst Evol Microbiol 51, 425-431.

Spring, S., Ludwig, W., Marquez, M. C., Ventosa, A. \& Schleifer, K.-H. (1996). Halobacillus gen. nov., with description of Halobacillus litoralis sp. nov. and Halobacillus trueperi sp. nov., and transfer of Sporosarcina halophila to Halobacillus halophila comb. nov. Int J Syst Bacteriol 46, 492-496.

Tamaoka, J. \& Komagata, K. (1984). Determination of DNA base composition by reversed-phase high-performance liquid chromatography. FEMS Microbiol Lett 25, 125-128.

Tanasupawat, S., Shida, O., Okada, S. \& Komagata, K. (2000). Lactobacillus acidipiscis sp. nov., and Weissella thailandensis sp. nov., isolated from fermented fish in Thailand. Int J Syst Evol Microbiol 50, 1479-1485.

Tanasupawat, S., Thawai, C., Yukphan, P., Moonmangmee, D., Itoh, T., Adachi, O. \& Yamada, Y. (2004). Gluconobacter thailandicus sp. nov., an acetic acid bacterium in the $\alpha$-proteobacteria. J Gen Appl Microbiol 50, 159-167.

Tanasupawat, S., Pakdeeto, A., Namwong, S., Thawai, C., Kudo, T. \& Itoh, T. (2006). Lentibacillus halophilus sp. nov., from fish sauce in Thailand. Int J Syst Evol Microbiol 56, 1859-1863.

Thompson, J. D., Gibson, T. J., Plewniak, F., Jeanmougin, F. \& Higgins, D. G. (1997). The CLUSTAL_X windows interface: flexible strategies for multiple sequence alignment aided by quality analysis tools. Nucleic Acids Res 25, 4876-4882.

Thornley, M. J. (1960). The differentiation of Pseudomonas from other Gram-negative bacteria on the basis of arginine metabolism. J Appl Bacteriol 23, 37-52.

Ventosa, A., Garcia, M. T., Kamekura, M., Onishi, H. \& RuizBerraquero, M. (1989). Bacillus halophilus sp. nov., a moderately halophilic bacillus species. Syst Appl Microbiol 12, 162-165.

Wayne, L. G., Brenner, D. J., Colwell, R. R., Grimont, P. A. D., Kandler, O., Krichevsky, M. I., Moore, L. H., Moore, W. E. C., Murray, R. G. E. \& other authors (1987). International Committee on Systematic Bacteriology. Report of the ad hoc committee on the reconciliation of approaches to bacterial systematics. Int J Syst Bacteriol 37, 463-464.

Yoon, J.-H., Kang, K. H. \& Park, Y.-H. (2002). Lentibacillus salicampi gen. nov., sp. nov., a moderately halophilic bacterium isolated from a salt field in Korea. Int J Syst Evol Microbiol 52, 2043-2048. 